\title{
NACHT, LRR and PYD Domains-Containing Protein 4
}

National Cancer Institute

\section{Source}

National Cancer Institute. NACHT, LRR and PYD Domains-Containing Protein 4. NCI

Thesaurus. Code C111918.

NACHT, LRR and PYD domains-containing protein 4 (994 aa, 113 kDa) is encoded by the human NLRP4 gene. This protein may be involved in the modulation of signaling in inflammation. 